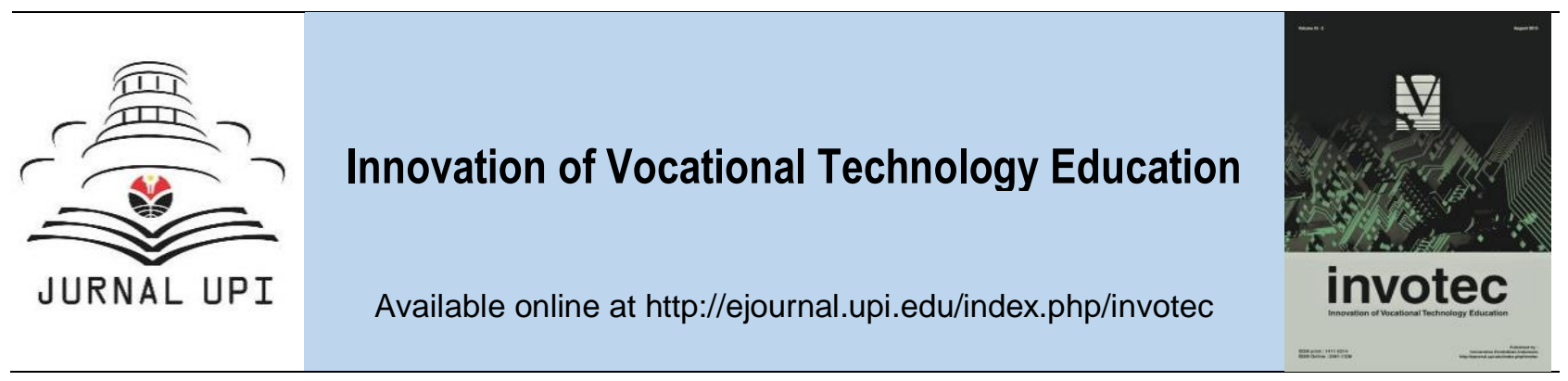

\title{
Industrial Education Impact on Vocational Student Social Skills
}

\author{
V. Dwiyanti, A. Ana, I. Widianingsih \\ Universitas Pendidikan Indonesia, Indonesia
}

\section{ARTICLE INFO}

\author{
A B S T R A C T
}

Article history:

Received 30 May 2018

Received in revised form 2 June 2018

Accepted 2 August 2018

Available online 31 August 2018

Keywords:

industrial impact,

social skills,

vocational education

Corresponding author:

vinadwiyanti@upi.edu
Industrial education is a dual system learning between industry and school. In this learning of vocational high school must fulfill industry and school qualification. Industrial education will help student to know and understand industry demand. In disruption and industry revolution 4.0 era more skills must had by them, such as social skills. This research method used literature review to see more resources about industrial education impact on vocational student social skills. And this research result is found two more important social skills. First, adaptability is a skill will help students to know and understand industry work and world, such as how to use technology, follow all industry SOP, all new chalanges industry, etc. Second, communication is an important skills to had. Because it will deliver us to make another understand all massage in verbal and non verbal clearly. They will help student to prepare and face human-robot competition in industry revolution 4.0 in the future.

\section{Introduction}

Industrial education has succeeded in answering challenges in meeting industrial needs (Jensen, 1993). Some countries such as America, Germany, Nigeria, Jordan and Malaysia show significant results in the competence of vocational secondary education graduates (Husain, et. al., 2010). In addition, American and Chinese countries have succeeded in providing a giant picture of world companies through the application of industrial approaches that are applied in schools (Burmeister, Luettgens, and Piller, 2015; Mukhtar and Ahmad 2015). Vocational secondary education graduates are required to be competent and have good social skills, so they are able to interact, adapt and cooperate well in the workplace (Burmeister, Luettgens, and Piller, 2015; de Guzman and Choi, 2013; Oviawe, 2010).

Students who have poor social skills will have difficulties in the area of education, vocational and work environment (Gresham, at. al., 2011). While in the industrial era 4.0 and the disruptrion phenomenon will change various fields including the replacement of industrial workers by robots that are considered more effective and efficient (Qin, Liu, and Grosvenor, 2016; Velde, 2009: Ismail, 2009). Then, the capacity of vocational secondary education students must able to adjust to a dynamic industrial shift (Fligstein, 2001; Lane, Pierson, and Givner, 2004). Having good social skills capable of competing with a variety of good.

Communication and adaptability are an important part of vocational secondary education students in preparing rapid interaction changes such as changes in human-computer interaction to computer-humans (Mukhtar and Ahmad, 2015; Sanders, Elangeswaran, and Wulfsberg, 2016; Williams, 2005). This phenomenon has happened in Germany in 2014, where 238 of the 1,000 
workers have been replaced by robots, so workers are unemployed because they are considered unable to fulfill industrial qualifications and are shifted by robots (Qin, Liu, and Grosvenor, 2016). This then became a new industry qualification and the challenge amid the era of disruption to this fourth industrial revolution (Reeve, 2016).

This literature review focuses on industrial education in Vocational High Schools (SMK). It is expected that this literature review can help students, teachers and researchers to find out the social skills characteristics that SMK students must have. And it is hoped that it can be used by teachers and researchers as information to identify social skills problems of vocational students to face the challenges of the fourth industrial revolution.

This literature review is presented with preliminary systematics that briefly describes industrial education and social skills. Writing method through the stages of searching and selecting articles / journals with the appropriate topics and the next stage are analyzed. As well as the relevant topics, methods and research findings are poured into the results, a discussion to support the writing of this literature review.

\section{Method}

This research method is divided into two main parts, namely the search and sorting phase and the data analysis stage. This research is limited to the topic of industrial education and social skills in vocational secondary education. Then further review of this topic refers to empirical findings. The first step is to search and sort electronic databases using key words industrial education and social skills. This electronic database is used as a reference for research obtained from ERIC, TandFonline, Ensiclopedia Special of Education and researchgates.

The next stage is the data analysis stage. Where the database has been collected and sorted and then analyzed according to the purpose of writing this literature review. Each article is read, analyzed and summarized by paraphrasing the research method, results and/or discussion according to the needs of writing this literature review study. This is done repeatedly for all databases that have been owned and according to the topic of this research topic.

\section{Result and Discussion}

\subsection{Industrial Education}

The experience often referred to in Germany about the importance of industrial education needs to pay attention to the objectives of industrial education itself (Dewey, 1977). Statistics available in Germany show that the effect of industrial education on wages does not appear to be different, skilled workers receive wages that are no more than unskilled workers. But the influence of industrial education on the wages or happiness of individual workers is not the most important thing.

Germany claims fairly that the application of a systematic, continuous system of military affairs, public education, civil administration and trade has the same roots and convergent goals. The welfare of the state as a moral entity is the highest. Promotion of companies against international competitors is one of the main means to advance the country. Industrial education is a means to create equality and justice in industry, especially for industry and workers (Stevenson, 1992). There is a tendency for some educators to minimize the importance of industrial education. This deliberation was partly due to a lack of respect for teaching needs in this field and partly because of a lack of information about the content of the programs offered. As the aim of the implementation of industrial education is to prepare students to be ready to work in the industry (Hadi, et.al, 2015).

Industrial education is combined between learning in industry and class. Pressure on industry needs that make this important industrial education to be implemented (Reeve, 2016). Because industry demands greater connectivity and interaction from machines and systems with Industry 4.0 capability in factories, manufacturing system suppliers must expand the role of Information and Technology (IT) in their products. Changes will likely include a larger modularization function with the application and enhancement of overall system functionality and complexity (Rüßmann, et. al. 2015). In addition, online portals for downloading software and collaborative partner relationships can offer equipment configurations that are more flexible and adaptable. Since 1973 during the industrial revolution to date, the development of the industrial 
economy has not been significant (Jensen, 1993). Therefore, collaborative efforts between industry and educational institutions are important in preparing industry-standard workers, as has been done in Europe with the establishment of Collaborative Working Groups (CWG) (Abelea, et. al., 2015). In addition, for the success of the industrial education program partners are needed who continue to share ideas about education, training, and research (Lee, Kao, and Yang, 2014; Velde, 2009). Then each school needs to provide special education and training that enables the scenarios and methods used in learning to prepare students for modern industry 4.0 (Faller and Feldmúller, 2015). Scenario-based Industry Learning 4.0 currently implemented at the first 4.0 Industrial Pilot Plant in Austria. This concept builds on tentative competency models for Industry 4.0 and the use of scenarios for problem-oriented learning from industry and describes the competency profile of workers in the future (Erol, et. al., 2016; Prinz, et. al., 2016).

\subsection{Social Skills}

Every industry has jobs with different levels of quality and / or the quality of work in the service industry is very diverse (Meisenheimer,1998). Then one of the tasks of educational institutions is to align graduate outcomes better with industry demand and look for employers' perceptions of future trends (Velde, 2009). In addition to hard skills and soft skills, social skills become one of the categories of workers who can fill the industrial space amid the 4.0 industrial revolution. The ability of students to cooperate becomes an important part of entering the industry (Gresham, et. al., 2011). In the literature this review is limited to adaptability and communication. Where these two capabilities are an important part of the shifting and changing demands of a rapidly changing industry.

\subsubsection{Adaptibility Ability}

When students are in a new environment with a variety of different cultures, including work culture, students will learn to adapt and communicate well. The results of research in Texas show that new environments have a major impact on students' adaptation and communication skills (Williams, 2005). Because humans are biopsychosocial creatures as a whole, in meeting their needs, people are always faced with complex problems, so they are required to adapt (Khandu, 2014). In addition, students must be able to adapt to the work environment(Gresham, et. al., 2011) and have the willingness and desire to work and study. Adaptability is supported by perseverance, resilience and moral character, namely integrity, fairness, empathy and ethics. These characters must be formed both at school and at work to help active and responsible individuals (Rocha, 2012). This shows that human factors as workers in the industrial era 4.0 must have the ability to control or use smart equipment well, have good performance to support the system applied to workers. One thing to note is the ability of workers to adapt to disruption phenomena in the industrial era 4.0 (Jones, et.al., 2017).

\subsubsection{Comunication Ability}

The ability to communicate effectively aims to provide convenience in understanding the message given. In the world of work, communication is one of the capabilities that must be possessed to be able to convey and receive and respond to information well, so that it can help the work process properly (Table 1). Effective form of communication (Fligstein, 2001):

Table 1. Forms of Effective Communication

\begin{tabular}{|c|c|}
\hline Effective Verbal Communication & Non Verbal Communication \\
\hline Take place reciprocally. & a. Physical appearance. \\
\hline $\begin{array}{l}\text { b. The meaning of the message is concise } \\
\text { and clear }\end{array}$ & $\begin{array}{l}\text { b. Attitudes and ways of walking } \\
\text { c. Facial expressions }\end{array}$ \\
\hline c. Language is easy to understand & \\
\hline d. Easy delivery method & \\
\hline e. Sincerely conveyed & \\
\hline f. Has a clear purpose & \\
\hline g. Shows the prevailing norms. & \\
\hline
\end{tabular}


Communication skills can not only speak and participate in conversations, discussions and meetings, but also be able to read and interpret written information, communicate thoughts, ideas, information and messages in written form and listen and respond to messages, both through verbal and gesture or body language (Hermann and Pentek, 2015). Communication skills are also demonstrated by being able to communicate in a foreign language, be able to listen to others, can communicate ideas that are well-owned, can voice agreement and disagreement well, and can understand spoken and written languages (Hermann and Pentek, 2015; Seliger, 2016).

\section{Conclusion}

Industrial education is combined between learning in industry and class. Pressure on industry needs that make this important industrial education to be implemented. In industrial education they get more experiences, such as how to solve problem, communicate with many people and background, adaptation in industry work also. In this research, two more important skills found. They are adaptability and communication skills. Adaptibility is a skills to deliver student in industry and also help them to know and use all new thing . Except it, communication is important to help student deliver all verbal and non verbal message to understand. SMK student must prepare to face industry revolution 4.0 where industry demand will increase. SMK students must fulfill it well, because they will compete with robot and they must win it.

\section{References}

Abelea, E., Metternicha, J., and Tischa, M., Chryssolourisb, G., Sinnc, W., EIMaraghyd, H., Hummele, V., and Ranze, F. (2015). Learning Factories for Research, Education, and Training. Procedia CIRP 32(Clf), 1-6. http://dx.doi.org/10.1016/j.procir.2015.02.187.

Burmeister, C., Luettgens, D., and Piller, F.T. (2015). Business Model Innovation for Industrie 4.0: Why the 'Industrial Internet' Mandates a New Perspective on Innovation. Ssrn, 124-52. http://dx.doi.org/10.2139/ssrn.2571033

De Guzman, A. B., and Choi, K,O. (2013). The Relations of Employability Skills to Career Adaptability among Technical School Students. Journal of Vocational Behavior, 82(3), 199-207. http://dx.doi.org/10.1016/j.jvb.2013.01.009.

Dewey, J. (1977). On Industrial Education. Curriculum Inquiry, 7(1), 53-60.

Faller, C., and Feldmúller, D. (2015). Industry 4.0 Learning Factory for Regional SMEs. Procedia CIRP, 32(Clf), 88-91. http://dx.doi.org/10.1016/j.procir.2015.02.117.

Fligstein, N. (2001). Social Skill and the Theory of Fields. Sociological Theory, 19(2), 105-125. http://www.jstor.org/stable/3108627.

Gresham, F. M., Elliott, S.N., Vance, M. J., and Cook, C. R. (2011). Comparability of the Social Skills Rating System to the Social Skills Improvement System: Content and Psychometric Comparisons Across Elementary and Secondary Age Levels. School Psychology Quarterly, 26(1), 27-44.

Ismail, R. 2009. Technical Efficiency, Technical Change and Demand for Skills in Malaysian Food-Based Industry. European Journal of Social Sciences, 9(3), 504-15. http://www.scopus.com/inward/record.url?eid=2s2.070349625597\& partnerlD=40\&md5= e95a6308b2a33e465939899ef77471e0. 
Jensen, M. C. 1993. The Modern Industrial Revolution, Exit, and the Failure of Internal Control Systems the Failure of Internal Control Systems. Journal of Finance, 48(3), 831-80. http://papers.ssrn.com/sol3/CiteReader_IN.cfm?abid=1364827\& requesttimeout=90000 \%5Cnhttp://onlinelibrary.wiley.com/doi/10.1111/j.1540-6261.1993.tb04022.x/pdf.

Jones, C. P., P. Waters, Kiel, A., Delaila, D., Abdullah, A., Salleh, M. Y., Drath, M. A. M., Horch, R., Amsden, A., Jeanmonod, A. H., Jeanmonod, D., Mudin, R., Kamarudin, D., Eng, D., Rahman, H. S., Ibrahim, M., Jopony, P., and Marimuthu, M. T. (2017). Innovative ideas: Thailand 4.0 and the fourth industrial revolution. International Association for Management of Technology, 2(1), 4-35. http://link.springer.com/chapter/10.1007/978-1-4020-81866_18 \%0Ahttp://ieeexplore.ieee.org/document/6839101/\%0Ahttp://ovidsp.ovid.com/ovidweb.c gi?T=JS\&P GE=reference \&D=yrovftd\&NEWS=N\&AN=00002311-199911240-00061

Lane, K. L., Pierson, M. R., and C. Givner, C. C. (2004). Secondary Teachers' Views on Social Competence. The Journal of Special Education, 38(3), 174-86. http://journals.sagepub. com/doi/10.1177/00224669040380030401.

Lee, J., Kao, H. A., and Yang, S. (2014). Service Innovation and Smart Analytics for Industry 4.0 and Big Data Environment. Procedia CIRP, 16, 3-8. http://dx.doi.org/10.1016/j.procir. 2014.02.001.

Meisenheimer, I. J. R. (1998). The Services Industry in the 'good' versus 'bad' Jobs Debate. Monthly Labor Review, 121(2), 22. http://search.ebscohost.com/login.aspx?direct=true\& $\mathrm{db}=\mathrm{bth} \& \mathrm{AN}=1209896 \&$ site $=$ ehost-live.

Mukhtar, I. M., and Ahmad, J. (2015). Assessment for Learning: Practice in TVET. ProcediaSocial and Behavioral Sciences, 204, 119-26. http://linkinghub.elsevier.com/retrieve/pii/ S1877042815047722.

Hadi, M. Y. A. Hassan, Razzaq, R., Mustafa, A. R. A., and Zaid, M. (2015). Application of Thinking Skills in Career: A Survey on Technical and Vocational Education Training (TVET) Qualification Semi-professional Job Duties. Procedia Social and Behavioral Sciences, 211, 1163-1170. http://linkinghub.elsevier.com/retrieve/pii/S1877042815054956.

Husain, M. Y., Mokhar, S. B., Ahmad, A. A., and Mustapha, R. (2010). Importance of employability skills from employers' perspective. International Conference on Learner Diversity (ICELD). Univ Kebangsaan, Bangi, Malaysia, Oct 19-20. Proceedings of International Conference on LearnerDiversity 2010. Procedia - Social and Behavioral Science, 7, (pp. 430-438)C.

Oviawe, J. I. (2010). Repositioning Nigerian Youths for Economic Empowerment through Entrepreneurship Education. European Journal of Educational Studies, 2(2), 113-18.

Prinz, C. M., Freith, F., Kreggenfeld, S., Kreimeier, N., Kuhlenkötter, D., B. (2016). Learning Factory Modules for Smart Factories in Industrie 4.0. Procedia CIRP, 54, 113-18. http://dx.doi.org/10.1016/j.procir.2016.05.105.

Qin, J., Liu, Y., and Grosvenor, R. (2016). A Categorical Framework of Manufacturing for Industry 4.0 and beyond. Procedia CIRP, 52, 173-78. http://dx.doi.org/10.1016/j.procir. 2016.08.005.

Reeve, E. M. (2016). $21^{\text {St }}$ Century Skills Needed By Students in Technical and Vocational Education and Training. Asian International Journal of Social Sciences, 16(4), 65-82. aining (TVET). https://doi.org/10.29139/aijss.20160404. 
Rocha, M. (2012). Transferable Skills Representations In A Portuguese College Sample: Gender, Age. Adaptability and Vocational Development, 27(1), 77-90. http://dx.doi.org/10.1007/ s10212-011-0067-4

Rüßmann, M. L., Gerbert, M., Waldner, P., Justus, M., Engel, J., and Harnisch, P. M. (2015). Industry 4.0. The Future of Productivity and Growth in Manufacturing. Boston Consulting (April): 1-5. http://dx.doi.org/ 10.1007/s12599-014-0334-4

Sanders, A, Elangeswaran, C. and Wulfsberg, J. (2016). Industry 4.0 Implies Lean Manufacturing: Research Activities in Industry 4.0 Function as Enablers for Lean Manufacturing. Journal of Industrial Engineering and Management, 9(3), 811-33.

Stevenson, J. (1992). Australian Vocational Education: Learning from Past Mistakes? The Vocational Aspect of Education, 44(2), 233-44. http://www.tandfonline.com/doi/abs/ 10.1080/10408347308003941.

Seliger, S. T. G. (2016). Opportunities of Sustainable Manufacturing in Industry 4.0. Procedia CIRP, 40(1), 536-541. http://dx.doi.org/10.1016/j.procir.2016.01.129

Hermann, T. M., and Pentek, T. (2015). Desingn principles for industrie 4.0 scenarios: a literature review, 1, 3-15. http://dx.doi.org/ 10.13140/RG.2.2.29269.22248

Velde, C. (2009). Employers' Perceptions of Graduate Competencies and Future Trends in Higher Vocational Education in China. Journal of Vocational Education and Training, 61(1), 3551.

Williams, T. R. (2005). Exploring the Impact of Study Abroad on Student's Intercultural Communication Skills: Adaptability and Sensitivity. Journal of Studies in International Education, 9(4), 356-71.

Khandu, Y. (2014). Ministry of Labour and Human Resources, Bhutan). TVET Online Issues 3. www.tvet-online.asia. 